\title{
Groundwater Protection as an Essential Component of Water Management in the European Union in the Light of Modern Integration Processes: Legal Aspects of the Problem
}

\author{
By Iryna Iefremova ${ }^{1}$, Iryna Lomakina ${ }^{2}$, Nataliia Obiiukh ${ }^{3}$
}

\begin{abstract}
In the context of exacerbation of environmental problems that are global in nature, it is necessary to assess the opportunities and development prospects of environmental policy not only at the international level, but also at the regional European level. In this regard, the focus of our article is to consider the problem of protecting groundwater as a strategic natural resource and to analyze the practice of applying European directives on water quality and protection of groundwater in EU countries. In the EU, the basic legal framework for water protection is defined in the Water Framework Directive that determines the need to develop monitoring programs and basin water management plans to improve the quality of water in the EU by the member states. However, taking into account the fact that groundwater, especially drinking artesian water, is vulnerable to pollution, improvement of the legal groundwater protection system and the search for rational groundwater protection practices implemented in the EU countries are vitally necessary. Therefore, the paper aims to explore the ways of EU legislation development in the field of water resources protection, identifying the main areas of groundwater protection and analyzing the legal means used in certain EU countries, in particular, Austria, Germany, as well as identifying priorities and objectives for Ukraine on the way to integration into the system of European water legislation.
\end{abstract}

Keywords: EU legislation, groundwater, groundwater pollution, groundwater use, water management, water protection.

\section{Introduction}

We live in a world where nearly one million people do not have access to drinkable water and nearly 2.6 million people have no appropriate hygiene items. Water is a vitally important natural wealth. According to UN international program documents, access to safe water and sanitation is one of the key factors in human health and dignity. In the course of its existence, human has tried to master all available natural resources. But, unfortunately, the environment has been damaged and natural balance in ecosystems has been disturbed. Technogenic loading on the environment causes various structural and qualitative changes, which negatively affect the condition of natural objects - water, air, soils, subsoil, etc. Despite the growing environmental crisis that the

${ }^{1} \mathrm{Ph} . \mathrm{D}$ in Law, associate professor, head of the Department of Civil Law Disciplines of Bila Tserkva National Agrarian University, Ukraine.

${ }^{2} \mathrm{Ph} . \mathrm{D}$. in Law, associate professor of the Department of Civil Law Disciplines of Bila Tserkva National Agrarian University, Ukraine.

${ }^{3}$ Ph.D. in Law, assistant professor of the Department of Civil Law Disciplines of Bila Tserkva National Agrarian University, Ukraine. 
world struggles to tackle, water quality issues are a major environmental and social problem for most countries.

In Ukraine, anthropogenic impact on water resources is increasing. " $80 \%$ of centralized drinking water supply is provided due to surface waters that subject to anthropogenic pollution, which, taking into account the inefficient performance of water treatment plants, poses a serious problem in obtaining high-quality drinking water. Significant amount of organic and inorganic pollutants that get into drinking water pose a real threat to the nation health, especially under radiation conditions" (UA press, June 24, 2012).

At the same time, the tendency towards deterioration of groundwater quality caused by excessive use of fertilizers in agriculture, as well as violation of waste management requirements is noticeable. This results in the appearance of unwanted dissolved components that pollute the groundwater.

Groundwater pollution is one of the serious global problems for social life, human health and the natural environment. More than 700 pollutants, their metabolites and transformation products are present in the European aquatic environment. One should take into account the fact that pollutants entering the water pools form various complex substances. Significant number of potentially toxic compounds and their spreading can cause synergistic effects (Petrie et al, 2015).

Also, along with groundwater pollution, there arises a problem of its quantitative depletion. It should be noted that groundwater depletion occurs when rates of groundwater recharge are less than rates of discharge. Over the last 50 years, groundwater depletion from direct or indirect effects of climate change and human activities has expanded from a local issue to one that affects large regions in many countries throughout the world (Green, 2016: 111).

Recently, the EU countries have been actively discussing the problem of so-called "diffuse pollution". In most European countries, agricultural activity is the main source of diffuse pollution. Agricultural diffuse pollution of water resources caused by losses of agro-chemicals and manure (including nutrients and pesticides) from land to water is a particular challenging and on-going issue (Mellander et al, 2018: 4)

Currently, polluted aquifers can no longer be considered as those affected by point sources as urban areas are bordered by agricultural and natural areas as a result of urban sprawl and a significant number of potential sources of pollution cause diffuse pollution. Therefore, the main issue for European countries is the definition of priority areas for groundwater protection from existing threats to preserve the stability of aquatic ecosystems (surface and groundwater).

Given the above problems, the issue of proper groundwater protection is of particular importance.

\section{Groundwater Protection in the Context of European Directives}

The European Union principal legislative acts in the field of groundwater protection is the Water Framework Directive adopted by the Council of Europe in 2000 (hereinafter referred to as the WFD) and Directive 2006/118/EC on the protection of groundwater against pollution and deterioration of December 12, 2006 (Groundwater Directive). The Water Framework Directive is the basic legal act that defines the 
principles of the EU water policy and sets requirements for Member States to reach "good quality status" for all water resources in the EU by 2015.

Important provisions concerning the groundwater protection in the EU are set out in Art. 4 of the Directive. The environmental objectives are aimed at: to prevent or limit the input of pollutants into groundwater and to prevent the deterioration of the status of all bodies of groundwater; to protect, enhance and restore all bodies of groundwater, ensure a balance between abstraction and recharge of groundwater with the aim of achieving good groundwater status; to implement the measures to reverse any significant and sustained upward trend in the concentration of any pollutant resulting from the impact of human activity in order to reduce pollution of groundwater (Directive 2000/60/EC, 2000).

It should be noted that the WFD establishes the mandatory application of the basin approach in water resources management, providing the system of monitoring of water bodies status and submission of information by the competent authorities. The basin councils that are set up to manage the river basin are advisory bodies. Their main task is the development and implementation of river basin management plans, providing information on the status of the use of the river basin. The river basin management plans should take into account groundwater protection measures that meet the requirements of integrated water resources management.

The remarkable achievement of the WFD is that this legal document considers water environment as a holistic natural system that includes water resources (surface and groundwater) and the connected ecosystems. The Directive specifies that the protection of the aquatic environment should be aimed at improving the status of aquatic ecosystems, as well as terrestrial ecosystems and wetlands directly depending on the aquatic ecosystems. In order to achieve the relevant objectives, the WFD stresses the need for a review of the impact of human activities on the status of water bodies, as well as the establishment of programs for water ecosystems status monitoring.

Groundwater monitoring provides the basis for environmental solutions planning, evaluation and adoption. The monitoring network should be provided with information on the chemical and quantitative status of the available groundwater. At the same time, special attention should be paid to evaluation of the chemical status of groundwater bodies that have been exposed to significant anthropogenic influences.

The monitoring system for groundwater chemical status provides two types of monitoring: 1) control monitoring; 2) operational monitoring. The control monitoring aims to supplement and confirm the impact assessment procedure, as well as to provide information on the pollutants that get into water due to anthropogenic activity. This monitoring is carried out on selected groundwater areas in order to control key parameters such as oxygen content, $\mathrm{pH}$, electrical conductivity, nitrates, ammonia (Directive 2000/60/EC, Annex V).

Operational monitoring should be carried out in order to: firstly, establish the chemical status of all groundwater bodies determined as being at risk; and secondly, to establish the presence of a long-term anthropogenic tendency to increase the concentration of any pollutant substance. This monitoring is carried out for all those groundwater bodies that are at risk for the ability to achieve the environmental objectives set in Art. 4 of the WFD. 
With regard to the groundwater chemical status, the monitoring network will have to be designed in order to provide a coherent and comprehensive overview of the groundwater chemical status within each river basin and to detect the presence of longterm anthropogenically induced upward trends in pollutants. Based on the results of the characterisation of groundwater bodies and the impact assessment, Member States will have to establish a surveillance monitoring programme, the results of which being used to establish an operational programme in the framework of each river basin management plan (Quevauviller, 2005: 95-96).

Human impact assessment is another important component of groundwater protection in the framework of the WFD. The impact assessment should include the information on the location of points in the groundwater body used for the abstraction of water; the annual average rates of abstraction from such points; the chemical composition of water abstracted from the groundwater body; the location of points in the groundwater body into which water is directly discharged; the chemical composition of discharges to the groundwater body (Directive 2000/60/EC, Annex V).

It is believed that the quality of groundwater depends to a large extent on the nature of land use as well as on climate change. However, there has been a tendency to increase anthropogenic impact on urban areas in recent years in the regions where agriculture interacts with the natural environment and urban settlements. This situation is typical for many European regions. The impact of various sources of pollution on the urbanized territories causes the emergence of new pollutants that were not included in national and international monitoring programs before.

Currently, the problem of emissions in water bodies is closely related to the problem of diffuse pollution. Diffuse pollution is a pollution that has a cumulative effect on natural ecosystems and combines the effects on groundwater aquifers, the accumulation of persistent pollutants in water bodies, the impact on water-living organisms and so on. Diffuse pollution occurs when potentially-polluting substances leach into surface waters and groundwater as a result of rainfall, soil infiltration and surface runoff. Typical examples of diffuse pollution include the use of fertilizer in agriculture and forestry, pesticides from a wide range of land uses, contaminants from roads and paved areas (Foundation for Water Research, 2015).

In the UK, farming is one of the main sources of diffuse water pollution. According to the Department of Ecology, Food and Agrarian Relations (DEFRA) farming contributes around $50-60 \%$ of nitrates, $20-30 \%$ of phosphorus and $75 \%$ of sediment getting into surface waters. DEFRA provides advice and some financial assistance to farmers with reducing pollution on their land. As part of this, Natural England runs the catchment sensitive funding programme in partnership with the Environment Agency and DEFRA which aims to reduce the level of diffuse pollution that farming can cause. Farmers and land managers in 77 catchments thought England were also able to apply for water capital grants of up to $\mathcal{E}^{10,000}$ per holding for infrastructure works to help reduce water pollution from agriculture up to 30 April 2015 (Priestley, 2015: 22).

Directive $2006 / 118 / \mathrm{EC}$ on the groundwater protection against pollution and deterioration provides detailed information on the means to achieve the WFD requirements on the groundwater protection. The Directive establishes that the level of nitrates should not exceed $50 \mathrm{mg} / \mathrm{l}$, whereas the levels of active ingredients of pesticides 
and their metabolites can not exceed $0.1 \mathrm{mg} / 1$ if it is necessary to achieve a "good status". And furthermore, the Member States should set threshold values for pollutants, groups of pollutants that characterize groundwater as being at risk of not achieving a "good chemical status" (Directive 2006/118/EC, 2006).

Directive 2006/118/EC is complementary to the WFD in the context of the legal regulation of groundwater protection. It should be noted that "the Directive establishes a clear legal obligation to prevent the input of hazardous chemicals into groundwater. This underlines the fact that the EU does not accept these chemicals should be present in groundwater and thus recognizes the intrinsic value of unpolluted groundwater and the importance of applying the precautionary approach when protecting such a vulnerable resource" (Cunningham et al, 2006: 12).

Of course, there are some ambiguities in the Directive itself. Some of its provisions are not entirely clear. First, unified approaches regarding the registration of hazardous pollutants are not agreed upon; and secondly, it does not provide explanation concerning the cases when the authorities have the right to make decisions on the prohibition or restriction of dumping the dangerous substances.

As we can see, groundwater has become a fragile resource in the 21 st century. In spite of its properties for natural regeneration, the problem of groundwater quality, especially in intensive farming areas, remains extremely important for European countries.

The experience of some countries applying management practices in the field of groundwater protection and use is worth demonstrating to evaluate the effectiveness of European groundwater protection programs.

\section{Groundwater Protection in the EU Countries: Experience in Applying the EU Directives Requirements}

\subsection{Groundwater protection measures in Austria}

About $50 \%$ of Austria's drinking water comes from groundwater aquifers. Most of the groundwater bodies are connected with large alpine drainage systems, such as the Danube, Salzach and Inn rivers. Austrian alpine basins and river valleys are not only favoured catchments fro groundwater recharge and important groundwater reservoirs but are also preferred areas for settlements, agricultural or industrial activities. Thus, anthropogenic influences such as water extraction for the drinking water supply can influence the groundwater-surface interaction (Hilberg \& Eisendle-Flockner, 2016: 122123).

The Federal Act on Water Law (WRG, 1959) creates the basis for groundwater protection in Austria. Directives concerning emissions and immissions, also as concerning groundwater protected zones and groundwater prevention areas are the basis for water protection (Herlicska, 2001).

The main objectives of the modern water policy of Austria are the development and implementation of measures to prevent groundwater pollution (within the framework of the Austrian Environmental Program for agricultural use), as well as control over the use of nitrogen fertilizers. Austria has achieved better groundwater protection through government programs for the establishment and operation of groundwater protection zones. 
Establishing protective zones in groundwater locations is particularly effective in controlling contamination from diffuse sources. At the same time, elementary approaches such as the system of permits, the regulation of pollutant emissions, etc. are used to control the point sources of influence. Thus, effective regulatory control of diffuse pollution often relies upon prohibition or restrictions of polluting activities in specific protected areas where impacts on groundwater sources are likely to be serious (Chave et al, 2006: 466).

The Federal Act on Water Law establishes the protection zones to protect water bodies from pollution spreading. According to water legislation there are three different types of protection zones (prescribed as decree) or groundwater prevention areas (issued as ordinance). Groundwater prevention areas are issued when it is necessary to prevent large areas. It is also possible to issue prevention areas for future groundwater use (Herlicska, 2001).

The protection zone I provides the protection of the well or source from any negative impact. The protection zone II has to protect the groundwater against bacterial contamination. The time of groundwater flow from the random of this zone to the well or spring has to be 60 days at minimum. The protection zone III has the task to prevent groundwater from persistent contaminants.

The maintenance of high-quality drinking water supply from groundwater wells is possible only with the availability of appropriate sanitary protection zones as their main function is to limit the economic activity impact on water bodies. Therefore, groundwater should be securely protected.

Assessment of groundwater aquifers fragility makes the basis for determining the boundaries of groundwater protection zones. The fragility of groundwater reveals the degree of subterranean waters and aquifers sensitivity to pollution. Of course, it depends on the depth of groundwater, the permeability of rocks, and the supply of groundwater. The fragility of groundwater indicates exactly the degree to which the quality of underground water varies under the influence of anthropogenic activities, in particular during land use as well as water use.

At present, there are about 200 large protection zones (with an average surface area of about $38 \mathrm{~km}^{2}$ ) and 1900 small protection areas. The protection areas cover some $10 \%$ of Austrian territory and are subject to special groundwater protection provisions of the Austrian Water Law (Dimkic et al, 2008: 88).

\subsection{The system of groundwater cooperative management in Germany}

Groundwater nitrate pollution is main problem for Germany since it is largely caused by the use of manure to fertilize plants in agricultural production. Although nitrate is important for crops to grow, the excessive use thereof can lead to residues in groundwater which are damaging to human health. Currently, Germany is second only to Malta in terms of groundwater nitrate pollution in the EU. The most polluted are Lower Saxony, Rhine Westphalia and Bavaria.

German agriculture is embedded in an intricate structure of regulative law for the protection of environment. For groundwater protection, regulative legal instruments apply like liquid manure application allowances or the establishment of groundwater 
protection areas with firm restrictions for agricultural producers. Since liquid manure and excessive fertilizer application are the main sources of diffuse groundwater pollution by agriculture, the successful implementation of these instruments is pivotal in federal states like Lower Saxony. More than two third of Lower Saxon agricultural value comes from animal production.

The Lower Saxon Co-operation Model program has been proposed by the government to promote local adapted initiatives. The program makes the legal basis for cooperation with farmers. Drinking water resources protection is of common interest, which can be realized through activities to protect groundwater developed by local associations called "co-operations". The realization of groundwater protecting measures, which are devised by so-called "groundwater co-operations", is financed out of this fee. About $€ 27.5$ million are annually allocated to cooperative groundwater protection as well as to nature conservation programs for the protection of water bodies in Lower Saxony (Bluemling \& Horstkoetter, 2006: 4).

There are currently 115 groundwater co-operations in Lower Saxony covering about 300 thousand hectares, more than 12 thousand types of equipment and almost 400 water intakes (Witte, 2002). In addition, financial support is provided by a series of measures to be implemented by different stakeholders, i.e. farmers, agricultural extension and water suppliers. They can apply for financial means which are administrated by the Lower Saxon Corporation of Water Supply and Nature Conservation under the auspices of the Ministry of the Environment.

In the context of the Lower Saxon Co-operation Model, voluntary agreements have become an important tool in the implementation of water protection measures. Special fee for water extraction is to be paid by water associations to provide water protection measures financial support. As regards to agriculture, the fee should be spent: for monetary compensation of impediments on agriculture in drinking water extraction areas; for subsidies to water suppliers for the purchase or lease of agricultural land in water protection areas; for the compensation of compulsory cultivation of riparian zones on agricultural land (Bluemling \& Horstkoetter, 2006: 5). Consequently, the activities of local co-operations aim to develop agriculture taking into account the objectives of water resources protection.

Another important area for groundwater protection in Germany is the control of fertilizers use in agriculture. The main tool for achieving the objectives of the EU Nitrate Directive is the government Fertilizer Application Ordinance (DüV). This legal act was adopted in 2007. It focused on reducing the amount of emissions of nitrogen used in agricultural activity.

In 2017, new rules regulating limits on mineral and organic fertilizers use were adopted. According to the requirements of the Fertilizer Application Ordinance 2017, the amount of organic nitrogen must not exceed $170 \mathrm{~kg} \mathrm{~N} / \mathrm{ha}$, except for winter wheat crops, which allows $230 \mathrm{~kg} \mathrm{~N} / \mathrm{ha}$. The main element of fertilizer planning is the nutrient balance of excess nitrogen - no more than $50 \mathrm{~kg} \mathrm{~N} /$ ha (Kuhn, 2017), which meets the requirements of the EU Nitrate Directive.

However, despite the measures taken to reduce nitrate pollution, Germany failed to achieve the objectives of Directive 91/676/EC. In June 2018, the European Court of Justice assumed Germany exceeding the limits for nitrogen use, which contravened the 
Nitrates Directive. The reason for this was that the Directive was not properly implemented (European Commission Press Release, April 28, 2016).

\subsection{Spain experience in the field of groundwater protection}

In Spain, groundwater accounts for $19 \%$ of the drinking water supply. Water consumers play a key role in groundwater use. All users in the aquifer are required to organize themselves into Groundwater User Associations (GUAs). These associations can represent the interests of users and cooperate with Basin Agencies in the in the design and implementation of management plans (Molinero et al, 2008).

The Water Act of 1985 defines the establishment of GUAs as a compulsory requirement for aquifers that are considered over-exploited. By their legal status, they are not private organizations, but public corporations. Their activities are regulated by the Water Act, and the decisions are agreed with the Basin Agencies. They are democratic organizations and manage the aquifers on a voluntary basis.

The first water association was created in 1976 in the Delta of the Llobregat River in Barcelona as a result of social alarm caused by rapid depletion of the water table as well as deteriorating water quality in the aquifers. This led to an increase in the cost of water purification and abstraction, which had the potential of endangering the survival of cities and key industries in the area (Llamas, 2002).

In terms of organizational types for participatory groundwater management, we can identify two types of systems: on the one hand, collective wells that are managed to surface water systems, where individual farmers take "shares" on a common well owned in a cooperative arrangement with other farmers and, on the other the exploitation of individuals wells by farmers to achieve a highly productive agriculture. In the case of Spain there is evidence that most cooperative arrangements for groundwater management have been created due to external incentives, yet have arise spontaneously (Lopez-Gunn et al, 2013).

The Water User Associations take part in the participatory boards of River Basin Authorities. They are active stakeholders seeking to safeguard their own interests in various matters such as the guarantee of the water volumes granted in the administrative concessions, the effective use of public funds for investment in irrigation works, the equitable establishment of tariffs and levies for the repayment of these public investments and the demands of publicly-funded irrigation management programs (Garrido\& Ramon Llamas, 2009: 122).

Groundwater communities in Spain are legally part of the administration in this case, river basin authorities. Thus there are true public-and-private partnerships where there are two main benefits: first, these groundwater user groups are entitled to receive public funds for their operation and on occasion sign one off agreements for specific issues and second, they can impose sanctions on their members when these are on points of fact not of law. The main condition of collective agreements in public-and-private partnership is that the water rights exist in the form of a public concession rather than private water rights (Llamas, 2002).

Experience in groundwater management in Spain shows the importance of educational campaigns, the direct involvement of water users in decision-making, the precise 
definition of water rights, and increased attention to the problem of groundwater pollution.

The WFD establishes a framework for joint environmental policy activities in the field of water policy; its main objective is water resources protection by development and implementing effective mechanisms for strategic water resources protection, such as regulation of harmful emissions, ensuring a monitoring system taking into account current environmental requirements.

As defined by the WFD, groundwater monitoring is a mandatory requirement for EU Member States; the goals and objectives of the monitoring should be included in the program of activities within the framework of the River Basin Management Plan. The monitoring network of groundwater quality is an integral part of the National groundwater conservation plan. Groundwater monitoring is carried out taking into account the basin water resources management, and control of groundwater monitoring is the responsibility of the River Basin Associations.

The purpose of groundwater monitoring is to obtain and study data on the operational stocks of groundwater, the level of their distribution in aquifers, compliance of qualitative characteristics of groundwater for the purposes of their use and analysis of the influence of anthropogenic factors on groundwater.

Depending on the purpose and object of the study, the monitoring system for groundwater includes three groups of observations. Primary monitoring, which provides an assessment of the trends in human impact on groundwater due to land use and climate change. Secondary monitoring is the basis for developing measures for the groundwater protection, in particular those used for drinking water supply of the population as well as for irrigation purposes. Tertiary monitoring involves identifying and analyzing the effects of the main sources of groundwater pollution - intensive agricultural land use, industrial and domestic waste (Foster et al, 2004).

In Spain, about $73 \%$ of groundwater is used for irrigation and intensive use of groundwater is a common practice. There is also some evidence of increasing pollution of groundwater from pesticides, despite lower use in many cases, largely explained by the long time pesticides can take to leach through soils into aquifers. In Spain, 173 groundwater bodies have been declared to be in poor status due to this type of pollution (De Stefano et al, 2015). Therefore, in the context of the European Strategy for nitrate pollution overcoming, groundwater monitoring and control by competent authorities are the main regulatory tools.

\section{Legal Aspects of Groundwater Protection in Ukraine within the Framework of National Legislation Adaptation to the EU Legislation}

Mineral fertilizers, liquid waste from animal husbandry complexes, organic waste, as well as waste generated as a result of underground mines exploitation are the main negative factors that pollute groundwater in Ukraine.

Of particular concern in Ukraine is a significant deterioration in the quality of water resources in the eastern Ukraine. One of the reasons for the unsatisfactory ecological state of surface and groundwater resources is their long-term pollution with untreated or insufficiently treated waste water from sewage and treatment facilities. Utilization of 
wastewater is carried out by the soil methods, which is a potential ecological and epidemic danger to public health (Ukrinform, 2018).

In Ukraine, the use of groundwater as a water resource is regulated by the norms of the Water Code of Ukraine. At the same time, relations in the field of groundwater extraction (the procedure and conditions for granting permits, requirements for subsoil users, payments) are determined by the norms of the Code of Ukraine on Mineral Resources.

Groundwater is a special natural resource that is a kind of water bodies and can be the object of subsoil use. The feature of relations regulation in the field of groundwater use and protection is that the legislative norms indicate the predominant application of the requirements of the Code of Ukraine on Mineral Resources when it comes to the use of groundwater as special subsoil use, as well as to the management and monitoring in the field of groundwater protection.

\subsection{Groundwater monitoring system in Ukraine}

At present, the "Regulation on the Approval of the Water Monitoring Procedure" of July 20, 1996 is the legal basis for water bodies monitoring in Ukraine. According to the Regulation, groundwater and springs, as well as seawater are the objects of state water monitoring (Cabinet of Ministers of Ukraine, 1996). State monitoring of waters provides the information received by monitoring entities in the course of observations as well as generalized data on a certain time period or a certain area and assessment of water status and sources of negative influence.

In Ukraine, the organization and monitoring of groundwater is covered by the terms of reference of the State Service of Geology and Mineral Resources of Ukraine which is a special body in the field of subsoil use. The groundwater monitoring system is based on the existing network of observation points (at the beginning of 2017, 635 deposits of drinking and technical groundwater, 250 mineral water deposits are explored in Ukraine). Therefore, the Dnieper River basin management plans for groundwater are to be developed in the nearest future since it is a critical task for the implementation of the EU Water Framework Directive (State Service of Geology and Mineral Resources, 2018).

Of course, it is expedient to create an appropriate legislative framework for ensuring WFD requirements for monitoring water facilities and planning measures to achieve a good quality status of all water resources in the context of the transition to a basin water resource management. The adoption of the Law of Ukraine "On Amendments to Certain Legal Acts of Ukraine Regarding the Implementation of Integrated Approaches into the Water Resources Management Following the River Basin Principle" of October 4, 2016, which came into force in January 2017, is a positive step in this regard.

As defined in this Law, "river basin management plans are developed and implemented in order to achieve the environmental objectives defined for each river basin district. Among the main elements of the river basin management plan are the following: general characteristics of surface and groundwater; defining zones to be protected; a list of targets for surface waters, groundwater and protected areas; economic analysis of water use; list of competent authorities" (Verkhovna Rada of Ukraine, 2016).

According to the provisions of the WFD, the surface and groundwater state monitoring programs provide a concerted and complete analysis of the condition of water in each 
area of the river basin, and for groundwater such programs are to include monitoring of their chemical and quantitative status. It is worth noting that European legal documents are quite democratic as they are mostly recommendatory - the right to freely choose observation points, the list of most controlled indicators and frequency of the observations etc. are specified in the national programs (Shestopalov \& Lyuta, 2016).

The monitoring within the river basin is necessary for control over the spread of harmful pollutants in water facility, evaluation of the influence of a certain source of contamination on the state of groundwater including diffuse sources. Chemical monitoring of groundwater is to determine the permissible level of harmful influence of the pollutant, to prevent the increase in the concentration of such substances that could cause dangerous effects on the water body.

As it is established by "Regulation on the Approval of the Water Monitoring Procedure" (Cabinet of Ministers of Ukraine, 1996) improved monitoring of drinking groundwater quality requires particular attention as citizens are both subsoil water users and customers of such monitoring. They are obliged to keep track of the quality and the amount of water abstracted from water bodies and pollutants dropped as well as the status of water facilities in discharged areas. Their information is considered supplementary and is included in the official one only after it is confirmed by institutions of state water monitoring. The same is true for the owners of decentralized drinking water supply wells.

Integration of different subjects of monitoring, development of Unified Information System for Groundwater Monitoring, urgent development of the concept of reformation of the state system of groundwater monitoring considering the international experience and relevant directives of the European Union are important aspects of the formation of a modern water monitoring system in Ukraine.

\subsection{Ukraine's obligation on implementation of the requirements of nitrates directives under the Association Agreement with the EU}

Currently, in Ukraine there is a major problem of soil pollution by inorganic compounds of nitrogen with nitrates prevailing among the pollutants. The increase in contaminated soils and groundwater is related to irrational farming, ungrounded use of plant protection chemicals and mineral fertilizers in agriculture. All these inevitably result in negative changes that are reflected in the soils and groundwater quality and properties. Since agriculture is the principal sector of the economy of Ukraine, care should be taken to the problem of land and water resources conservation in land-use with agriculture focused on organic production.

The EU-Ukraine Association Agreement on May 29, 2014 (EU Association Agreement, 2014) which entered into force on September 1, 2017 contributes to determining ways of Ukraine's national policy convergence with the EU within the framework of European integration. Chapter 6 "Environment" of the Agreement outlines the main directions regarding changes in the environmental management system.

Implementation of the requirements of the WFD and its subsidiary directive - Directive $91 / 676 / \mathrm{EC}$ on the protection of waters against pollution caused by nitrates from agricultural sources is extremely important for Ukraine, especially in terms of 
implementation the principles of the WFD and the achievement of a "good environmental status" for water sources.

Directive 91/676/EC (also called the Nitrate Directive) is one of the main European legal documents, the obligation of which must be fulfilled by Ukraine. The Directive is aimed at reducing water pollution by nitrates compounds coming from distributed sources of agricultural origin and has a dual purpose: first, to reduce pollution of surface and groundwater from agricultural sources; and second, to prevent this pollution in the future.

Identification of vulnerable areas which are seen susceptible to nitrate pollution is an important tool for reducing the negative impact of agricultural sources. According to Nitrate Directive vulnerable zones are determined as the areas of land which drain into polluted waters or waters at risk of pollution and which contribute to nitrate pollution. The designation of vulnerable zones should be carried out within a two-year period after the Nitrate Directive implementation, and their review is carried out at least once every 4 years.

In order to ensure general level of water protection, Member States are to establish codes of good agricultural practice within two years from the notification of this Directive. The codes are to be implemented by farmers on a voluntary basis. Member States shall set up a program, including the provision of training and information for farmers, promoting the implementation of the codes of good agricultural practice (Directive 2006/118/EC, 2006).

In addition, Member States should establish action programs of measures for nitrate vulnerable zones to be implemented within four years from the date of their approval. They also have to develop and implement the necessary monitoring programs on nitrates content of waters (surface waters and groundwater) which make it possible to establish the extent of nitrate pollution in the waters from agricultural sources (Article 5.6 of Directive 91/676/EEC).

According to the requirements of the EU directives, the limit value for nitrates is fixed, namely: no more than $50 \mathrm{mg} / \mathrm{l}$ (for drinking water resources), for nitrites - 0,50 mg/l, pesticides $-0,10 \mu \mathrm{g} / \mathrm{l}$. If the concentration of nitrates in water bodies is higher or may exceed $50 \mathrm{mg} / \mathrm{l}$, such water bodies are characterized as contaminated, or those that are under the threat of contamination (Medinets et al, 2018).

In connection with the adoption of the Resolution of the Cabinet of Ministers of Ukraine of October 25, 2017 No. 1106 "About agreement performance about association between Ukraine, on the one hand, and the European Union, European Atomic Energy Community and their state members, on the other hand" (Cabinet of Ministers of Ukraine, 2017) the Government approved the Action Plan for the implementation of the basic provisions of the Association Agreement.

Also, in order to implement Directive 91/676/EC, the Action Plan was proposed. It stipulates the following steps: 1) the Ministry of Ecology and Natural Resources of Ukraine is to take measures to identify nitrate vulnerable zones and to implement the appropriate action plans; to develop and implement at the national level programs for monitoring nitrates content in water bodies; 2) the Ministry of Agrarian Policy of Ukraine is to adopt codes of good agricultural practice and the necessary programs for promoting the implementation of these codes. 
Therefore, the implementation of the requirements of the Nitrate Directive in Ukraine stipulates solving a number of complicated tasks related to bringing the soil and groundwater quality assessment system into line with European standards; compliance with European requirements for the use and storage of organic fertilizers and also the formation of a fair conduct by the farmer that meets the requirements of farming in modern conditions.

\section{Conclusions and Proposals}

In the context of water quality problem escalation, groundwater protection is one of the topical in European environmental law. The analysis of EU directives and legislative acts of certain EU countries which regulates the use and protection of groundwater, taking into account the experience of European countries in the field of management and protection of groundwater, allows making the following conclusions and proposals:

1. Management in the field of groundwater protection requires informed approaches taken by the competent authorities, compliance with the requirements of the directives, which define the basic principles and means of water resources protection, by the member states of the EU.

2. Relations in the field of groundwater and surface waters use and protection are regulated by the norms of the Water Framework Directive, which is aimed at achieving the "good" status of all water resources. As for groundwater, this task should be implemented through the development and implementation of groundwater monitoring programs by the Member States. The programs purposes are to determine the groundwater chemical status, as well as anthropogenic activities impact assessment. It is important that the network of monitoring observations should be developed for each river basin.

3. The mechanism for the groundwater protection in the EU countries is represented by a wide range of regulatory tools, such as a system of permits and prohibitions on harmful pollutants emissions, a system for monitoring the quantitative and chemical status of groundwater, an overview of the impact of anthropogenic activities on groundwater, and the control of the use of fertilizers and plant protection chemicals. According to the Groundwater Directive, the permissible content of nitrates in water should not exceed $50 \mathrm{mg} / \mathrm{l}$. These are the substances hazardous to all water bodies and they must be controlled strictly.

4. The experience of some EU countries shows that the implementation of the WFD and related directives requirements is a challenge requires reasonable approaches to decision-making in the field of water resources protection, the development of strategies, plans and recommendations for reducing the negative impact of human activity on the quality of water sources and creating favorable conditions for water use.

5. Thus, in Austria, governmental programs for the establishment of protected areas, especially for drinking water supply sources, are implemented in order to achieve the best results in the field of groundwater quality provision. In Spain, the establishment of relations between local associations of water users and state authorities promoting reliable water supply is a positive example to follow. Local cooperatives, like the one 
being implemented in Lower Saxony, are formed in Germany - they bring farmers together in order to obtain rights to use groundwater under improved conditions.

6. For Ukraine, the use of groundwater is a priority type of water use. In connection with the adoption of the Association Agreement between the EU and Ukraine, new directions of environmental policy and fulfillment of the requirements provided for in EU legal acts were outlined. Therefore, in order to achieve the goals of the WFD and the EU Nitrate Directive, it is necessary to improve the management system in the field of groundwater protection, to establish the competent authority, to adopt the new Regulation on monitoring of water bodies in Ukraine as well as to develop groundwater monitoring programs taking into account the principle of basin management and develop and implement the codes of good agricultural practice.

\section{References}

Bluemling, B. \& Horstkoetter, M. (2006). Agricultural Groundwater Protection through Groundwater Cooperations in Lower Saxony, Germany, - a multi stakeholder task. Actes du séminaire Wademed (novembre 6-7, 2006). Available at: http://hal.cirad.fr/cirad-00190911/document [Accessed 30.05.2019].

Cabinet of Ministers of Ukraine (1996). On Approval of the State Monitoring of Waters of 20 July 1996 No. 815. Available at: http://zakon.rada.gov.ua/laws/show/815-96-\%D0\%BF [Accessed 02.05.2019].

Cabinet of Ministers of Ukraine (2017). Resolution about association between Ukraine, on the one hand, and the European Union, European Atomic Energy Community and their state members, on the other hand of 25 October 2017 No. 1106. Available at: https://cis-legislation.com/document.fwx?tgn=105236 [Accessed 02.05.2019].

Chave P., et al. (2006), Groundwater protection zones; in: Schmoll O., Howard G., Chilton J. and Chorus I., eds., Protecting Groundwater for Health: Managing the Quality of Drinking-water Sources (United Kingdom: London). Available at: http://www.who.int/water sanitation health/publications/PGWsection4.pdf [Accessed 16.05.2019].

Cunningham R., et al. (2006). A critical assessment of Europe's groundwater quality protection under the New Groundwater Directive. Available at: http://www.wrrl-info.de/docs/wrrl_grundwasser_critical_assessment.pdf [Accessed 16.05.2019].

De Stefano, L., Fornes, J.M, Lopez-Geta, J.A. \& Villarroya, F. (2015). Groundwater use in Spain: an overview in light of EU Water Framework Directive. International Journal of Water Resources Development, 31 (4), 640-656. DOI: 10.1080/07900627.2014.938260.

Dimkic M., Brauch H.-J. and Kavanaugh M. (2008). Groundwater Management in Large River Basins. London: IWA Publishing.

Directive 2000/60/EC (2000). Directive 2000/60/EC of the European Parliament and of the Council of 23 October 2000 establishing a framework for Community action in the field of water policy. Official Journal of European Communities, 2000 L 327/1. Available at: https://eur-lex.europa.eu/legalcontent/EN/TXT/?uri=CELEX\%3A32000L0060 [Accessed 12.06.2019].

Directive 2006/118/EC (2006). Directive 2006/118/EC of the European Parliament and of the Council of 12 December 2006 on the protection of groundwater against pollution and deterioration. Official Journal of the European Union, 2006 L 372/19. Available at: https://eur-lex.europa.eu/legalcontent/EN/TXT/?uri=CELEX\%3A32006L0118 [Accessed 04.06.2019].

Foster, S., Tuinhoff, A. et al. (2004) Groundwater Monitoring Requirements for managing aquifer response and quality threats. Sustainable Groundwater Management: Concepts and Tools, Briefing note 9, 2004. Available at: http://documents.worldbank.org/curated/en/334871468143053052/pdf/301070BriefingNote9.pdf [Accessed 26.04.2019].

Green, T.R. (2016). Linking Climate Change and Groundwater: 97-141. In: Anthony J. Jakeman, et al., eds. Integrated Groundwater Management. Springer, 2016. DOI: 10.1007/978-3-319-23576-9 5

Herlicska, H. (2001). Groundwater protection and drinking water supply in the federal province of Burgenland (Austria). Available at: https://www.unece.org/fileadmin/DAM/env/water/meetings/groundwater01/austria.pdf [Accessed 20.05.2019]. 
Hilberg, S. \& Eisendle-Flockner, U. (2016). About faunal life in Austrian aquifers - historical background and current developments. Austrian Journal of Earth Sciences, 109 (1), 2016, 119-134. DOI: 10.17738/ajes.2016.0009.

Kuhn, T. (2017). The revision of the German Fertiliser Ordinance in 2017. Agricultural and Resource Economics, Discussion Paper, 2, 2017. Available at: http://www.ilr.unibonn.de/agpo/publ/dispap/download/dispap17 02.pdf [Accessed 20.05.2019].

Llamas, R. Groundwater and aquifer management. Available at: http://siteresources.worldbank.org/INTMNAREGTOPWATRES/Resources/Spain2002-C2.pdf [Accessed 28.05.2019].

Lopez-Gunn, E., Rica, M. and Llamas, R. (2013). Can cooperation lead to improved performance in groundwater management? Some reflections on the experience of Spanish groundwater user groups. International Annual UN-Water Zaragoza Conference 2012/2013 Preparing for the 2013 International Year. Water Cooperation: Making it Happen! (January 8-10, 2013). Available at:

http://www.un.org/waterforlifedecade/water cooperation 2013/pdf/can user cooperation lead to impr oved groundwater management.pdf [Accessed 03.06.2019].

Medinets, S., Medinets, V., Kovalova, N. (2018). Analysis of EU Directives requirements on solving the problem of $\mathrm{N}$ load for the aquatic ecosystems. XXI International conference "Ecology, environmental protection and balanced environmental management: education - science - production 2018. Available at: http://dspace.onu.edu.ua:8080/bitstream/handle/123456789/17564/Medinets\%20S_Medinets\%20V.pdf?seq uence $=1$ \& ris Allowed $_{\mathrm{y}}^{\mathrm{y}}[$ Accessed 03.06.2019].

Mellander, P.-E., Jordan, Ph., Bechmann, M., et al (2018). Integrated climate-chemical indicators of diffuse pollution from land to water. Scientific Reports, 8, 2018, 1-10. DOI: 10.1038/s41598-018-19143-1

Molinero, J., et al (2008). Groundwater in Spain: Overview and management practices. Available at: http://www.rac.es/ficheros/doc/00587.pdf [Accessed 02.06.2019].

Petrie, B., Barden, R. \& Kasprzyk-Hordern, B. (2015). A review on emerging contaminants in wastewaters and the environment: current knowledge, understudied areas and recommendations for future monitoring. Water Resources, 72, 2015, 3-27. DOI: 10.1016/j.watres.2014.08.053

Priestley, S. (2015).Water Framework Directive: achieving good status of water bodies. House of Commons of Library Briefing Paper (November 27, 2015). Available at: https://www.legco.gov.hk/general/english/library/stay_informed_overseas_policy_updates/water_framewor k.pdf [Accessed 02.06.2019].

Quevauviller, Ph. (2005). Groundwater monitoring in the context of EU legislation: reality and integration needs. Journal of Environmental Monitoring, 7 (2), 2005, 89-102. DOI: 10.1039/B413869B

Shestopalov, V. \& Lyuta, N. (2016). Status and ways of reforming of the state groundwater monitoring system taking into account international experience and requirements of the EU Water Framework Directive. Mineral Resources of Ukraine, 2, 2016. Available at: http://ukrdgri.gov.ua/wpcontent/uploads/2016/07/mru 02 2016 02.pdf [Accessed 06.06.2019].

Stam, C. (2018). EU Court condemns Germany for exceeding nitrate limits. Available at: https://www.euractiv.com/section/agriculture-food/news/eu-court-condemns-germany-for-exceedingnitrate-limits/ [Accessed 04.06.2019].

UA press (2012). Water quality in Ukraine is one of the reasons for occurrence of malignant neoplasms. Available at: http://uapress.info/ru/news/show/4155 [Accessed 30.05.2019].

Ukrinform (2018). The experts identified the cause of surface water and groundwater pollution in the Donbas region. Available at: https://www.ukrinform.ua/rubric-regions/2480904-eksperti-nazvali-pricinizabrudnenna-poverhnevih-ta-pidzemnih-vod-na-donbasi.html [Accessed 04.06.2019].

Verkhovna Rada of Ukraine (2014). Association Agreement between the European Union and its Members, of the one part, and Ukraine, of the other part. Available at: https://zakon.rada.gov.ua/laws/show/984 011 [Accessed 12.06.2019].

Verkhovna Rada of Ukraine (2016). On Amendments to Certain Legal Acts of Ukraine Regarding the Implementation of Integrated Approaches into the Water Resources Management Following the River Basin Principle. Available at: http://zakon.rada.gov.ua/laws/show/1641-19 [Accessed 12.06.2019].

Water policy in Spain (A. Garrido \& M. Ramon Llamas, eds.). Washington: Taylor \&Francis Group, 2009.

Witte, F. (2002). Das Niedersächsische Kooperationsmodell - Erfahrungen sowie Anforderungen unter sich ändernden Bedingungen in der Agrar- und Umweltpolitik. 10 Jahre Trinkwasserschutz in Niedersachsen. 